ISSN 1412-2936

EISSN 2549-7308

\title{
Analisis Lingkungan Eksternal dan Internal Sebagai Dasar Penentuan Strategi Bersaing Pada AZWA Parfume
}

\author{
Khanzul Akhiar. \\ khanzul@gmail.com \\ Universitas Andalas
}

\begin{abstract}
ABSTRAK
Capturing business prospects in the perfume industry amid the current competition, a strategy is needed so that business growth through increasing market share can be achieved, and able to improve long-term corporate performance through identification of both internal and external factors so that the business strategy at AZWA Parfume can be achieved. provide an alternative business development strategy, the stages used are: the input stage using the IFE and EFE matrix, the matching stage using the TWOS matrix and the IE matrix and the decision stage using QSPM.The results showed that the competing strategies carried out were quite good even though they were not maximally seen as being weak in conducting promotions and needed training and development for HR, the weak promotion was due to untrained HR in using information systems, so that sales realization was far from the set targets. Where the actual opportunities that are owned are very large seen from the size of the existing market share. While the threat from competitors is very large with the quality of the production they have. But AZWA Parfume also has an advantage that can win the competition by looking at the many variants of parfume that have a unique, luxurious and halal aroma that can meet consumer needs. From the analysis conducted, it is expected that the company can win the competition by increasing promotion and developing HR.
\end{abstract}

Keywords: EFE Matrix, EFI Matrix, SWOT Matrix, IE Matrix, QSPM

\section{PENDAHULUAN}

Indonesia merupakan negara yang memiliki pasar yang besar dan dapat dikembangkan, hal ini mengindikasikan bahwa Indonesia memiliki potensi yang besar pada bisnis parfume. Potensi yang besar tersebut dapat dijadikan sebuah peluang untuk mengembangkan produk parfume menjadi sebuah bisnis yang dapat dimanfaatkan baik oleh penduduk lokal maupun wisatawan asing.
AZWA Parfume merupakan fragrance house dengan koleksi parfume exulisive yang khusus tersedia di otletoutlet azwa parfume. Aroma yang unik, mewah dan longlasting dengan essential kwualitas premium pilihan perusahaan perusahaan fragrance dunia menjadi keunggulan dari azwa perfume. Product quality dan service care adalah nilai dan prinsip azwa parfume dalam mengembangkan usahanya. Karena susah dalam pengucapan, Azzwar \& 
Sons Pd Parfum Paris berubah nama menjadi Azzwars Perfume pada 2010, kemudian berhasil meluaskan jangkauan Azzwar hingga memiliki 11 cabang di Padang, Lubuk Alung, Bukittinggi, juga Pekanbaru. Dengan mempekerjakan 45 karyawan, Azzwar menjadi salah satu penguasa bisnis parfum racikan di kawasan Sumatra Barat.

Tak cuma eksis di bisnis parfum refill, sejak 2003 mereka mulai memproduksi parfum sendiri. "Saat ini parfum yang dijual sudah $70 \%$ hasil desain aroma sendiri, sebanyak 250 jenis aroma, Sekitar 100 jenis aroma. Untuk masuk pasar global, Azzwar Perfume berganti nama menjadi Azwa. Kata Azwa diambil dari bahasa Arab yang berarti pusat perhatian dan kemegahan. Nama itu disiapkan untuk masuk pasar ASEAN. Selanjutnya, merek Azwa Perfume diperuntukkan pasar outlet premium, sementara merek Azzwars Perfume tetap dipertahankan untuk pasar menengah bawah. Merek Azwa Perfume menjual aroma atau jenis parfum dengan $100 \%$ rancangan sendiri.

AZWA Parfume berdiridikota padang sejak tahun 2002, menjual berbagai merek parfume exulusive dengan desain khusus dengan aroma yang wangi dan lembut dengan memakai bahan aman dan halal, dengan harga yang terjangkau. Kebutuhan masyarakat mendorong tercianya pangsa pasar yang lebih besar bagi industry parfume di Indonesia. Dapat kita lihat penjualan AZWA Parfume pada table dibawah ini dalam lima tahun terakhir.

\begin{tabular}{cc}
\hline & Data penjualan AZWA Perfume \\
\hline Tahun & Penjualan \\
\hline 2014 & Rp 1.130.289.500 \\
\hline 2015 & Rp 1.439.866.000 \\
\hline 2016 & Rp 1.719 .995 .000 \\
\hline 2017 & Rp 1.580 .999 .000 \\
\hline 2018 & RP 2.151.521.000
\end{tabular}

Sumber: AZWA Parfume

Hal ini dapat dilihat dari table di atas data penjualan AZWA Parfume dari tahun 2014 - 2018 masih mengalami data yang fluktuatif. Untuk penjualan tertinggi pada tahun 2018 sebanyak Rp.2.151.999.500 sedangkan penjualan terendah pada tahun 2014 sebanyak Rp.1.130.289.500. Dari data tersebut dapat dilihat perkembangan yang peluang yang cukup besar pada industry parfume di Indonesia.

Peluang yang besar tersebut tentunya dihadapkan pada tantangan yang semakin kuat, baik dari segi internal perusahaan ataupun eksternal perusahaan. Dilihat dari aspek internal perusahaan meliputi antara lain tuntutan perbaikan system dalam rangka peningkatan perofesionalisme dan transparasi, masih terbatasnya wilayah distribusi yang hanya meliputi kota Padang dan kota Pekanbaru, tuntutan perbaikan pelayanan serta tuntutan ketentuan hukum. Oleh sebab itu strategi AZWA Parfume harus berpusat kepada factor-faktor yang menciakan budaya pelayanan yang baik terhadap konsumen, meningkatkatkan sensitifitas terhadap kebutuhan konsumen,sehingga dapat memeberikan kenyamanan dan kepuasan terhadap konsumen, hal ini 
akan memberikan pengaruh yang lebih penting dari pada menwarkan rentang yang baik dari produk dan jasa (Bezborah \& Bhagawati, 2013). Sedangkan dari aspek eksternal azwa perfume saat ini lebih dominan dipengaruhi oleh kompetitor yang lebih kompetitif dalam melakukan strategi bersaing.

Persoalan yang menjadi masalah bagi produk dan pengembangan usaha AZWA Parfume ini yaitu masih terbatasnya wilayah distribusi yang dimiliki yang hanya meliputi kota Padang dan Pekanbaru, pemasaran dan pendistribusian produk yang kurang maksimal karena belum maksimalnya usaha untuk meningkatkan pemasaran produknya dengan memperbanyak jalur distribusi dan promosi, pengetahuan akan sistem pencatatan dan pembukuan perusahaan yang belum oimal, minimnya alat operasional produksi khususnya alat-alat produksi modern yang dapat mendukung kelancaran produksi dan pemasaran di lapangan, variasi botol produk yang dihasilkan baik dari segi bentuk dan kemasan. Selain itu, lebih konsumtifnya masyarakat sekarang terhadap parfume original dibandingkan dengan parfume lokal menjadikan pemilik menjadi lebih kesulitan untuk memasarkan produk tersebut, karena masyarakat sekarang menganggap parfume original adalah lifestyle mereka yang dapat meningkatkan prestise bagi kehidupan mereka dan menganggap parfume lokal sebagai produk yang ketinggalan zaman terutama bagi masyarakat perkotaan. Banyaknya produsen parfume yang memproduksi parfume original dan kebijakan perdagangan bebas Asean (AFTA) turut menjadi ancaman bagi perusahaan dan membuat persaingan semakin ketat dalam memperebutkan pasar.

\section{KERANGKA TEORI}

\section{Strategi Bersaing}

Dalam perkembangan, konsep mengenai strategi terus berkembang. Hal ini dapat ditunjukan oleh adanya perbedaan mengenai konsep strategi. Strategi dapat di artikan sebagai kreasi yang unik, memiliki posisi yang bernilai, meliputi serangkaian aktifitas yang berbeda dari kompetitornya (Porter,1996). Defenisi strategi ini menjelaskan tentang pentingnya inovasi dan kreasi yang memberikan nilsi dari setiap produk/jasa yang benar-benar berbeda dari pesaing di pasar. Inovasi dan kreasi yang dikombinasikan dalam produk atau jasa akan memberikan nilai untuk memperoleh keuntungan dalam bersaing.

Strategi merupakan alat mencapai tujuan. Srategi merupakan komitmen yang terintegrasi dan terkoordinasi yang dirancang untuk mengeksploitasi kompetensi inti dan mendaptkan keuntungan kompetitif. Ketika memilih strategi, perusahaan membuat pilihan antara alternative bersaing sebagai jalur untuk memutuskan bagaimana mereka akan mengejar keunggulan baersaing (Hitt,2001).

\section{Keunggulan Bersaing (Competitive Advantage)}

Keunggulan

bersaing (Competitive Advantage) merupakan proses dinamis, karenanya harus dilakukan berkesinambungan. Keunggulan bersaing menggambarkan suatu perusahaan dapat bertindak lebih baik dibandingkan perusahaanlain walaupun mereka bergerak dibidang industry yang sama. Sumberdaya dan 
skill dalam membangun karakteristik produk dan perusahaan dalam sebuah industry terbukti menciptakan posisi keunggulan bersaing yang kuat pada sebuah bisnis. Menurut Porter, jika di awal keunggulan bersaing dianggap identik dengan produktifitas ketika melewati analisis daya saing maka perusahaan dianggap yang paling sukses didunia internasional berdasarkan pangsa pasar mereka (Nisipeanu,2013).

Karena sifatnya yang tidak mudah ditiru, keungulan bersaing yang berkelanjutan merupakansatu strategi bersaing yang dapat mendukung kesuksesan suatu perushaan untuk jangka waktu yang lama. Umumnya perusahaan menerapkan strategi bersaing ini secara eksplisit melalui kegiatan-kegiatan dari berbagai departemen fungsionalperusahaan yang ada. Pemikiran dasar dari penciptaan strategi bersaing berawal dari pengembangan formula umum mengenai bagaimana bisnis yang akan dikembangkan, apakah sebenarnya yang menjadi tujuannya dan kebijakan apa yang diperlukan untuk mencapai tujuan tersebut. Dimana pengembangan strategi bisnis yang bersangkutan harus disesuaikan dengan kebutuhan konsumen sertadisesuaikan dengan kemampuan organisasi melalui ketersediaan sumberdaya dalam organisasi bisnis (Dirisu dkk,2013).

Faktor Penentu Keberhasilan (Keys Succes Factor)

Formulasi strategis atau yang biasanya disebut dengan perencanaan strategis merupakan proses penyususnan perencanaan jangka panjang. Oleh karena itu, prosesenya lebih banyak menggunakan proses analisis. Sebelum melakukan formulasi strategis, perusahaan harus memperhatikan dan melakukan pengamatan lingkungan usaha yang akan memberikan dan melakukan pengamatan langsung maupun tidak langsung dalam pengambilan keputusan. Pengamatan lingkungan perusahaan ini meliputi lingkungan internal perusahaan maupun lingkungan eksternal perusahaan.

\section{Analisis Lingkungan Eksternal perusahaan (EFE)}

Analisis lingkungan internal bertujuan untuk mengembangkan sebuah daftar terbatas dari peluang yang dapat menguntungkan sebuah perusahaan dan ancaman yang harus dihindarinya. Menurut Kotler dan Armstrong (2008) Analisis lingkungan eksternal perusahaan terdiri dari dua komponen pokok yaitu:

\section{Analisis Lingkungan Makro}

Lingkungan makro terdiri dari kekuatan sosial yang lebih besar yang mempengaruhi lingkungan mikro, terdiri dari lingkungan demografi, lingkungan ekonomi, lingkungan alam, lingkungan teknologi, lingkungan politik dan lingkungan budaya.

\section{Analisis Lingkungan Mikro}

Lingkungan mikro terdiri dari pelaku yang dekat dengan perusahaan dan mempengaruhi kemampuan perusahaan dalam melayani pelanggannya, terdiri dari pemasok, perantara pemasaran, pelanggan dan masyarakat

Selain lingkungan makro dan lingkungan mikro terdapat satu lagi lingkungan eksternal perusahaan yaitu lingkungan industri, dimana pada 
lingkungan ini akan lebih mengarah pada aspek persaingan industri di mana perusahaan saat ini berada. Menurut Rahmady dan Andi (2007), ada lima kekuatan yang mempengaruhi kekuatankekuatan dalam persaingan industri yang biasa disebut model lima kekuatan porter yaitu ancaman pendatang baru, ancaman barang pengganti, kekuatan tawar menawar pemasok, kekuatan tawar menawar pembeli dan persaingan dari perusahaan sejenis dalam industri

Analisis lingkungan perusahaan terbagi menjadi dua yaitu analisis lingkungan internal dan analisis lingkungan eksternal.

\section{Analisis Lingkungan Internal Perusahaan (IFE)}

Analisis lingkungan internal ini diperlukan untuk mengetahui kekuatan dan kelemahan bersaing. Menurut David (2010) faktor-faktor strategis internal yang dapat dianalisis yang dapat mempengaruhi kekuatan dan kelemahan internal yaitu manajemen, pemasaran, keuangan/akuntansi, produksi/operasi, penelitian dan pengembangan (litbang) dan Operasi Sistem Informasi Manajemen Perusahaan Informasi menghubungkan semua fungsi bisnis dan menyediakan landasan bagi semua keputusan manajerial.

\section{Matrik Internal-Eksternal (IE Matrik)}

Matriks Internal- Eksternal (IE) ini dikembangkan dari model General Electric (GE). Parameter yang digunakan meliputi parameter kekuatan internal perusahaan dan pengaruh eksternal yang dihadapi. Tujuan penggunaan model ini adalah untuk memperoleh strategi bisnis di tingkat korporat atau divisi unit bisnis yang lebih detail (Rangkuti, 2008).
Menurut David (2010) Matrik IE dapat dibagi menjadi tiga bagian besar yang berbeda-beda. Pertama, ketentuan untuk divisi-divisi yang masuk dalam sel I, II, dan IV dapat digambarkan sebagai tumbuh dan membangun. Kedua, divisi-divisi yang masuk dalam sel III, V, dan VII dapat ditangani dengan baik melalui strategi menjaga dan mempertahankan. Ketiga, ketentuan umum untuk divisi yang masuk dalam sel VI, VIII, dan IX adalah panen atau divestasi.

\section{Analisis SWOT}

Analisis SWOT (StrenghtsWeaknesses-Opportunities-Threats) adalah identifikasi berbagai faktor secara sistematis untuk merumuskan strategi pemasaran. Analisis ini didasarkan pada logika yang dapat memaksimalkan kekuatan dan peluang, namun secara simultan dapat meminimalkan kelemahan dan ancaman (Rangkuti, 2001). Kekuatan adalah kemampuan internal, sumber daya, dan faktor situasional positif yang dapat membantu perusahaan melayani pelanggannya dan mencapai tujuannya. Kelemahan adalah keterbatasan internal dan faktor situasional negatif yang dapat menghalangi performa perusahaan. Peluang adalah faktor atau tren yang menguntungkan pada lingkungan eksternalyang dapat digunakan perusahaan untuk memperoleh keuntungan. Ancaman adalah faktor pada lingkungan eksternal yang tidak menguntungkan yang menghadirkan tantangan bagi performa perusahaan (Kotler dan Armstrong, 2008).

Menurut David (2010), matrik SWOT adalah sebuah alat pencocokan yang penting yang membantu para manajer 
mengembangkan empat jenis strategi yaitu strategi SO (kekuatan-peluang), strategi WO (kelemahan-peluang), strategi ST (kekuatan-ancaman), dan WT (kelemahan-ancaman).

a. Strategi SO, Strategi yang memanfaatkan kekuatan internal perusahaan untuk menarik keuntungan dari peluang eksternal.

b. Strategi WO, Strategi yang bertujuan untuk memperbaiki kelemahan internal dengan cara mengambil keuntungan dari peluang eksternal.

\section{c. Strategi ST, Strategi yang menggunakan kekuatan sebuah perusahaan untuk menghindari atau mengurangi dampak ancaman eksternal.}

d. Strategi WT, Strategi taktik defensif yang diarahkan untuk mengurangi kelemahan internal serta menghindari ancaman eksternal.

\section{Matrik QSPM}

Tahap terakhir dalam perumusan strategi adalah tahap keputusan. QSPM (Quantitative Strategic Planning Matrix) adalah alat yang memungkinkan penyusunan strategi untuk mengevalusi alternatif strategi secara obyektif, berdasarkan faktor-faktor keberhasilan penting internal dan eksternal yang diidentifikasi sebelumnya (David, 2010). Perusahaan harus dapat mengambil keputusan tentang strategi terbaik dan paling cocok yang mereka miliki untuk diterapkan sesuai dengan kondisi internal dan eksternal perusahaan, yaitu setelah melalui tahap input dan pencocokan.

Secara konseptual, QSPM digunakan untuk menentukan daya tarik relatif dari berbagai strategi yang dibangun berdasarkan faktor-faktor keberhasilan penting eksternal dan internal perusahaan. Salah satu keistimewaan dari QSPM adalah bahwa rangkaian-rangkaian strateginya dapat diamati secara berurutan atau bersamaan. Keistimewaan lain dari QSPM adalah mendorong para penyusun strategi untuk memasukkan faktor-faktor eksternal dan internal yang relevan dalam proses pengambilan keputusan. Mengembangkan QSPM memperkecil kemungkinan bahwa faktorfaktor utama akan terlewat atau diberi bobot secara brlebihan. QSPM menggarisbawahi setiap hubungan penting yang dapat mempengaruhi pengambilan keputusan strategi. Walaupun dalam mengembangkan QSPM dibutuhkan sejumlah keputusan subjektif, membuat keputusan-keputusan kecil disepanjang proses meningkatkan probabilitas bahwa keputasan akhir yang diambil adalah yang terbaik bagi perusahaan.

\section{METODOLOGI}

Penelitian ini termasuk penelitian terapan (riset terapan) jika dilihat dari tujuan akhir penelitian ini adalah menyelesaikan masalah yang ada di lokasi penelitian. Tujuan penelitian dalam penelitian ini adalah penelitian eksploratif dengan studi kualitatif. Studi eksploratif tidak berhubungan untuk membahas apa yang akan terjadi, atau tidak ada informasi yang tersedia tentang masalah yang sama atau penelitian yang dibahas di masa lalu.

\section{Teknik Pengumpulan Data}

Pengumpulan data menggunakan beberapa metode yaitu : 1. Riset perpustakaan enelitian yang dilakukan dengan mengumpulkan dan mempelajari teori-teori yang berhubungan dengan masalah yang dibahasdari literature- 
literature, jurnal-jurnal, dan buku-buku. 2 . Riset lapangan. Penelitian lapangan ini digunakan untuk memperoleh data primer langsung dari objek yang akan diteliti melalui: a. Observasi, pengamatan langsung terhadap objek yang diteliti dan situasi pada objek.b. Metode wawancara, metode ini dilakukan dengan mengajukan pertanyaan lansung kepada pejabat berwenang. c. Kuisioner, kuisioner yang digunakan untuk mengetahui seberapa besar pengaruh factor internal dan eksternal terhadap perusahaan. Kuisioner memberikan perimbangan dalam menentukan bobot peringkat pada matriks IFE dan EFE. Pembobotan dalam kuisioner ini menggunakan skala rangking dengan metode "Paired Comparison" atau perbandingan berpasangan.

\section{Operasi Varaiabel}

Analisis SWOT adalah sarana analisis perusahaan melalui faktor-faktor strategis perusahaan (kekuatan, kelemahan, peluang, dan ancaman)

\section{Matrik IFE}

Analisis matrik IFE yang dilakukan pada AZWA Parfume dilakukan untuk menganalisis terhadap setiap factor lingkungan internal yang berpengaruh terhadap perusahaan. Hasil dari matrik IFE dapat dilihat pada Tabel berikut:

Tabel Matrik IFE

\begin{tabular}{|c|c|c|c|c|}
\hline No & Kekuatan & Bobot & Rating & Skor \\
\hline 1. & Manajemen yang Visioner dalam melihat peluang yang ada & 0,0802 & 3,33 & 0,2673 \\
\hline 2. & Budaya organisasi perusahaan yang sudah berjalan dengan baik & 0,0769 & 4,00 & 0,3074 \\
\hline 3. & Parfume Azwa original, unik, mewah dan halal. & 0,0770 & 4,00 & 0,3079 \\
\hline 4. & Tersebarnya store resmi AZWA Parfume dibeberapa daerah & 0,0758 & 3,33 & 0,2527 \\
\hline 5. & AZWA Parfume bekerjasama dengan perusahaan jasa pengiriman & 0,0735 & 3,33 & 0,2451 \\
\hline \multirow[t]{3}{*}{6.} & Media social merupakan salah satu kekuatan AZWA Parfume & 0,0883 & 3,00 & 0,2648 \\
\hline & Total Kekuatan & & & 1,6452 \\
\hline & Kelemahan & & & \\
\hline 7. & Realisasi penjualan yang tiap tahunnya belum tercapai & 0,0566 & 3,00 & 0,1698 \\
\hline 8. & Masih kurangnya melakukan Promosi & 0,0792 & 3,33 & 0,2641 \\
\hline 9. & Botol kemasan yang belum memiliki Inovasi & 0,0815 & 4,00 & 0,3260 \\
\hline 10 & Jumlah outlat resmi AZWA Parfume belum tersebar secara merata & 0,0588 & 2,67 & 0,1567 \\
\hline 11 & Gedung kantor yang masih dalam masa sewa & 0,0441 & 2,00 & 0,0881 \\
\hline 12 & Butuh penelitian dan pengembangan kembali tehadap produk & 0,0770 & 2,00 & 0,1539 \\
\hline 13 & Belum menggunakan system informasi Manajemen & 0,0656 & 3,33 & 0,2188 \\
\hline 14 & Kurangnya pelatihan dan pengembangan untuk SDM & 0,0656 & 3,33 & 0,2188 \\
\hline & Total Kelemahan & & & 1,5961 \\
\hline & Total & 1 & & 3,241 \\
\hline
\end{tabular}

Dari matrix IFE dilihat bahwa kekuatan utama yang dimiliki oleh AZWA Parfume adalah Brand AZWA Parfume yang original, unik, mewah dan halal dengan perolehan bobot 0,3079 , dimana banyak perusahaan parfume yang ada dengan mengusung konsep parfum refill atau isi ulang, AZWA Parfume dengan berani mengusung konsep parfume original $100 \%$ racikan sendiri dengan aroma yang unik, mewah dan longlasting. Untuk kelemahan yang dimiliki oleh AZWA Parfume adalah botol kemasan yang belum memiliki 
inovasi dengan skor 0,3260. Hal inilah yang mengakibatkan banyaknya masyarakat belum teralalu puas untuk produk AZWA Parfume, diharapkan dengan kekuatan yang dimiliki bisa meningkatkan market share dan daya saing AZWA Parfume. Skor total dari faktor internal adalah 3,241, ini menunjukan bahwa secara internal perusahaan memiliki banyak kekuatan dan mampu menangani kelemahan yang dimiliki.

\section{Matrik EFE}

Analisis Matrik EFE yang dilakukan pada AZWA Parfume dilakukan untuk menganilisis terhadap setiap faktor lingkungan eksternal yang berpengaruh terhadap perusahaan.Hasil dari matrik IFE dapat dilihat pada Tabel berikut:

Tabel Matrik EFE

\begin{tabular}{|c|c|c|c|c|}
\hline No & Peluang & Bobot & Rating & Skor \\
\hline 1. & Sedikitnya Pesaing dalam Industri Ini & 0,1010 & 3,33 & 0,3368 \\
\hline 2. & Kebutuhan masyarakat akan parfume dalam beraktifitas & 0,0934 & 4,00 & 0,3735 \\
\hline 3. & Trend masyarakat dalam berbelanja online & 0,0910 & 4,00 & 0,3640 \\
\hline 4. & Meningkatnya UMR masyarakat & 0,0948 & 3,00 & 0,2845 \\
\hline 5. & Besarnya pangsa pasar yang dapat diraih & 0,0985 & 3,67 & 0,3613 \\
\hline & Total Peluang & & & 1,7201 \\
\hline \multicolumn{5}{|c|}{ Ancaman } \\
\hline 6. & Produk refill atau merek lain & 0,1061 & 3,67 & 0,3889 \\
\hline 7. & Parfum Ori brandend & 0,0810 & 3,67 & 0,2972 \\
\hline 8. & Isu parfum Beralkohol & 0,0923 & 3,00 & 0,2768 \\
\hline 9. & Kuantitas order terbatas dari pemasok & 0,0710 & 2,67 & 0,1894 \\
\hline 10 & Nilai tukar dolar & 0,0973 & 3,33 & 0,3243 \\
\hline 11 & Pengiriman barang yang dibatasi oleh pihak jasa pengiriman & 0,0736 & 3,00 & 0,2207 \\
\hline & Total Ancaman & & & 1,6971 \\
\hline
\end{tabular}

Dari matrix EFE dilihat bahwa peluang utama yang dimiliki oleh AZWA Parfume adalah kebutuhan masyarakat meningkat dengan perolehan bobot 0,735 , peluang lain besarnya pangsa pasar yang dapat diraih dengan perolehan bobot 0,3613 . Untuk ancaman yang dimiliki oleh AZWA Parfume adanya ancaman dari produk refill atau merek lain dengan skor 0,3889 dan ancaman terbesar kedua adalah nilai tukar dollar terhadap rupiah dengan skor 0,3243 . Hal ini perlu diwaspadai dan ditanggulangi oleh AZWA Parfume. Skor total dari factor eksternal adalah 3,4172 , ini menunjukan bahwa secara eksternal perusahaan memiliki banyak pelung dan mampu menangani ancaman.

\section{Analisis Matriks TWOS dan Diagram TWOS}

Analisis

TWOS

diolah

berdasarkan analisis data yang diperoleh dari matrik EFE \& IFE. Analisis diagram TWOS dibagi atas beberapa strategi dalam empat sel yang berbeda. Berikut beberapa strategi hasilkan dari matrik TWOS:

1. Strategi S-O

Merupakan strategi, dimana perusahaan menghadapi beberpapeluang lingkungan dan kekuatan sehingga dimanfaatkan peluang yang ada. Adapun strateginya adalah Meningkatkan kualitas layanan dan melakukan promosi dengan 
didukung oleh teknologi sehingga memberikan kemudahan kepada konsumen.

2. Strategi W-O

Merupakan strategi dengan memperbaiki kelemahan yang dimiliki dengan memanfaatkan peluang yang dimilki, adapun strateginya adalah Gencar dalam melakukan promosi dan meningkatkan kualitas SDM terhadap system informasi

3. Strategi S-T

Merupakan strategi dengan memanfaatkan kekuatan yang ada agar ancaman yang ada dapat diatasi. Adapun strateginya adalah. Meningkat kualitas layanan dengan memperbanyak member dengan memberikan banyak keuntugan yang akan didapatkan kemudian dengan melakukan Menjaga hubungan baik dengan pihak pemasok.

4. Strategi W-T

Merupakan strategi dengan tujuan mengurangi kelemahan dan ancaman yang dihadapi perusahaan. Adapun strateginya adalah Gencar melakukan promosi dan meningkatkan kualitas produksi dan SDM.

\section{Diagram TWOS}

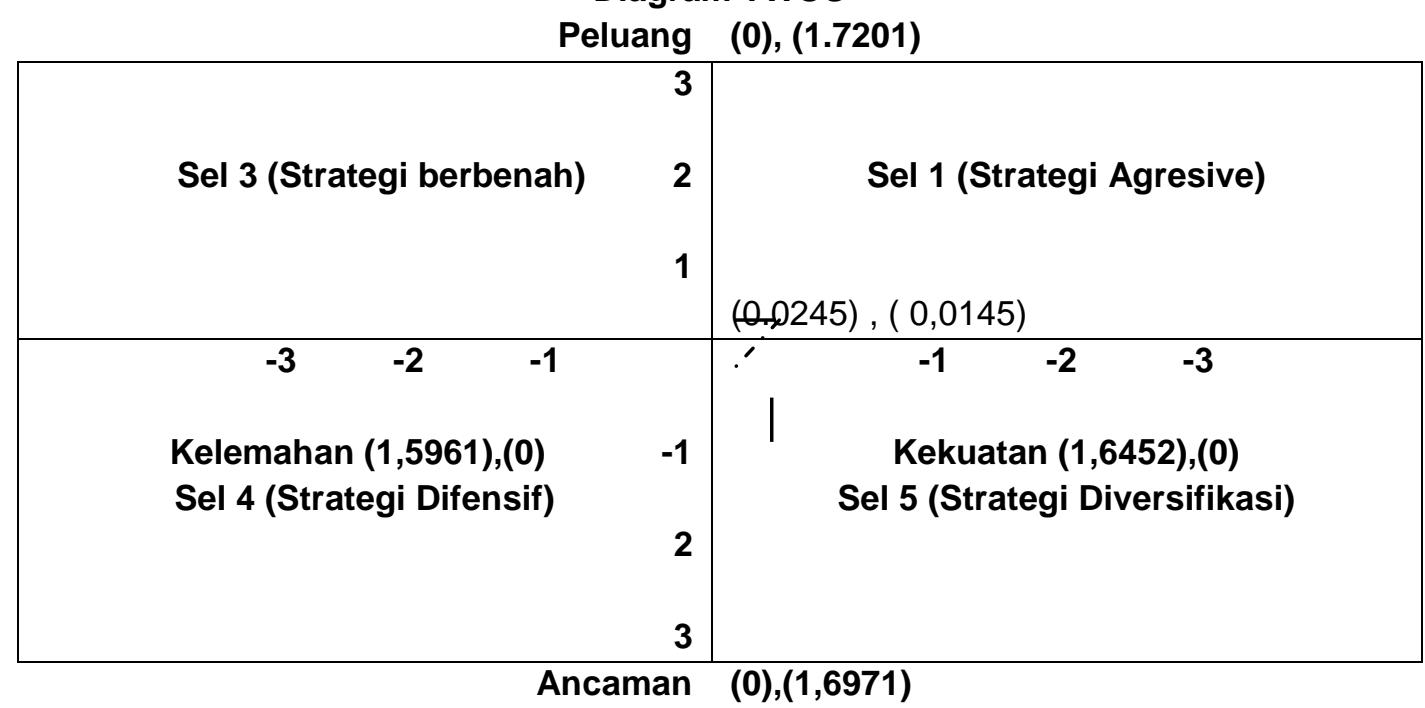

Analisis Kordinat Internal

$=$ ( Skor total kekuatan - Skor total kelemahan )

$=(1,6452)-(1,5961)=0.0491: 2=$ 0.02455

Analisis Kordinat Eksternal

$=($ Skor total peluang $)-($ Skor total ancaman )

$=(1,7201)-(1,6971)=0,0291: 2=$ 0,01455

Maka kordinatnya berada (0.02455), (0.01455)

Dari diagram TWOS dilihat bahwa posisi perushaan berada beradapada sel 1 yaitu sel agresif. Dimana merupakan strategi yang berada pada pertumbuhan. Perusahaan menghadapi peluang lingkungan yang banyak kekuatan yang mendorong peluang tersebut.

\section{Matriks Internal Eksternal (IE)}

Berdasarkan hasil dari matrik IFE dan IFE diperoleh skor matrik IFE sebesar 3.241 sedangkan hasil skor dari matrik EFE sebesar 3.4172, lalu dimasukkan kedalam matrik IE. Berdasarkan dari hasil skor tersebut jika dipadukan hasil dari matrik IFE dan hasil dari Matrik EFE kedalam matrik IE, strategi yang dilakukan berada dalam kuadran satu. Maka diperoleh stategi 
ISSN 1412-2936

EISSN 2549-7308

yang akan dilakukan. Strategi tersebut adalah strategi Grow and Build.
Adapun hasil dari Matriks Internal Eksternal (IE) dapat dilihat pada Gambar berikut:

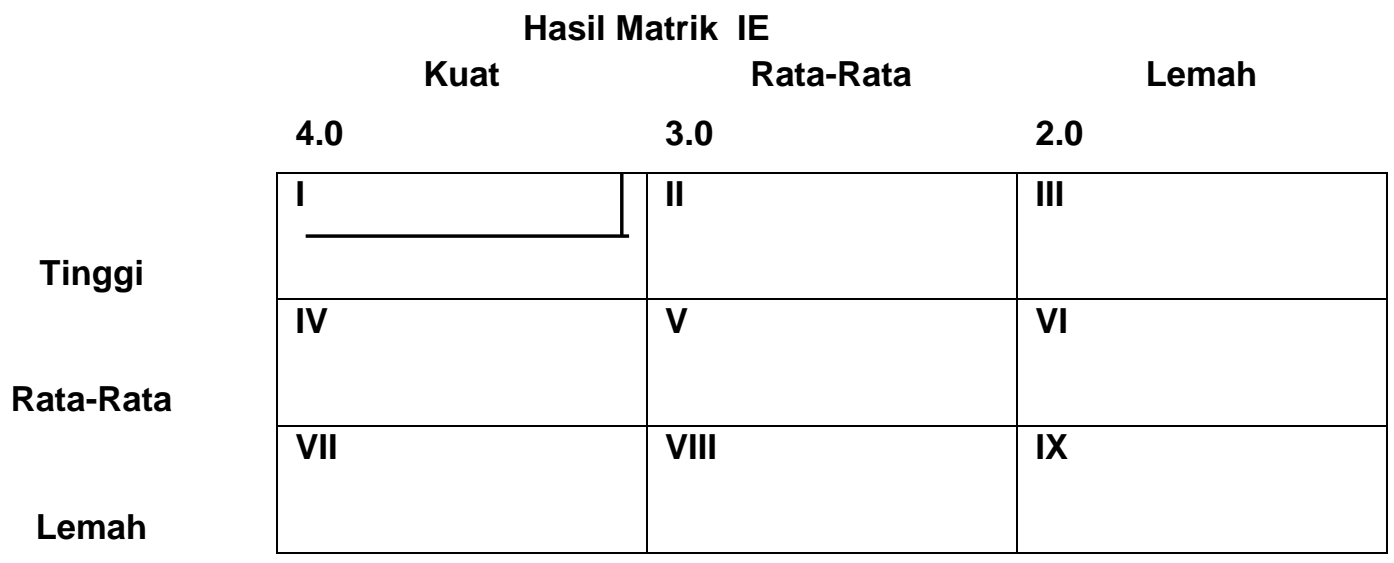

\section{QSPM (Quantitative Strategic Planing Matrix)}

Tahap akhir dari perumusan analisis strategi bersaing yaitupemilihan strategi terbaik dengan menggunakan alat analisis Quantitative Strategic Planing Matrix (QSPM). Berdasarkan hasil dari analisis IE dan SWOT.

\begin{tabular}{|c|c|c|c|c|c|c|c|c|c|}
\hline \multirow{2}{*}{$\begin{array}{l}\text { Faktor Kunci } \\
\text { Kekuatan }\end{array}$} & \multirow[b]{2}{*}{ Bobot } & \multicolumn{2}{|c|}{ STRATEGI 1} & \multicolumn{2}{|c|}{ STRATEGI 2} & \multicolumn{2}{|c|}{ STRATEGI 3} & \multicolumn{2}{|c|}{ STRATEGI 4} \\
\hline & & AS & TAS & AS & TAS & AS & TAS & AS & TAS \\
\hline $\begin{array}{l}\text { Manajemen yang } \\
\text { Visioner dalam melihat } \\
\text { peluang yang ada }\end{array}$ & $\begin{array}{c}0,080 \\
2\end{array}$ & $\begin{array}{c}3,3 \\
3\end{array}$ & 0,2673 & $\begin{array}{c}3,66 \\
7\end{array}$ & 0,2941 & 3,33 & 0,2673 & 3,33 & 0,2673 \\
\hline $\begin{array}{l}\text { Budaya organisasi } \\
\text { perusahaan yang sudah } \\
\text { berjalan dengan baik }\end{array}$ & $\begin{array}{c}0,076 \\
9\end{array}$ & 4 & 0,3076 & $\begin{array}{c}3,66 \\
7\end{array}$ & 0,2820 & 3,33 & 0,2563 & 2,67 & 0,2051 \\
\hline $\begin{array}{l}\text { Brand AZWA Parfume } \\
\text { yang original, unik, } \\
\text { mewah dan Longlasting }\end{array}$ & 0,077 & 4 & 0,308 & 4 & 0,308 & 3,33 & 0,2567 & 2,67 & $\begin{array}{c}0,2053 \\
3\end{array}$ \\
\hline $\begin{array}{l}\text { Tersebarnya store resmi } \\
\text { penjualan AZWA } \\
\text { Parfume dibeberapa } \\
\text { daerah }\end{array}$ & $\begin{array}{c}0,075 \\
8\end{array}$ & $\begin{array}{c}3,3 \\
3\end{array}$ & 0,2527 & 3 & 0,2274 & 3 & 0,2274 & 2,67 & 0,2021 \\
\hline $\begin{array}{l}\text { AZWA Parfume menjalin } \\
\text { kerja sama dengan } \\
\text { perusahaan jasa } \\
\text { pengiriman seperti } \\
\text { JNE,JNT dan Tiki. }\end{array}$ & $\begin{array}{c}0,073 \\
5\end{array}$ & $\begin{array}{c}3,3 \\
3\end{array}$ & 0,245 & 3 & 0,2205 & 3,33 & 0,245 & 2,67 & 0,196 \\
\hline $\begin{array}{l}\text { Media social merupakan } \\
\text { salah satu kekuatan } \\
\text { AZWA Parfume dalam } \\
\text { meningkatkan penjualan. }\end{array}$ & $\begin{array}{c}0,088 \\
3\end{array}$ & 3 & 0,2649 & 3 & 0,2649 & 3,33 & 0,2943 & 3,33 & $\begin{array}{c}0,2943 \\
3\end{array}$ \\
\hline Kelemahan & & & & & & & & & \\
\hline $\begin{array}{l}\text { Realisasi penjualan yang } \\
\text { tiap tahunnya belum }\end{array}$ & $\begin{array}{c}0,056 \\
6\end{array}$ & $\begin{array}{c}3,0 \\
0\end{array}$ & 0,1698 & 3 & 0,1698 & 3,67 & 0,2075 & 3,67 & 0,2075 \\
\hline
\end{tabular}


ISSN 1412-2936

EISSN 2549-7308

\begin{tabular}{|c|c|c|c|c|c|c|c|c|c|}
\hline $\begin{array}{l}\text { mencapai target yang } \\
\text { telah ditetapkan. }\end{array}$ & & & & & & & & & \\
\hline $\begin{array}{l}\text { Masih kurangnya } \\
\text { melakukan Promosi }\end{array}$ & $\begin{array}{c}0,079 \\
2\end{array}$ & $\begin{array}{c}3,3 \\
3\end{array}$ & 0,264 & 3 & 0,2376 & 4 & 0,3168 & 3,33 & 0,264 \\
\hline $\begin{array}{l}\text { Botol kemasan yang } \\
\text { belum memiliki Inovasi }\end{array}$ & $\begin{array}{c}0,081 \\
5\end{array}$ & 4 & 0,326 & 3 & 0,2445 & 3,67 & 0,2988 & 3,67 & 0,2988 \\
\hline $\begin{array}{l}\text { Jumlah outlat resmi } \\
\text { AZWA Parfume yang } \\
\text { belum tersebar secara } \\
\text { merata }\end{array}$ & $\begin{array}{c}0,058 \\
8\end{array}$ & $\begin{array}{c}2,6 \\
7\end{array}$ & 0,1568 & 2,67 & 0,1568 & 3 & 0,1764 & 3 & 0,1764 \\
\hline $\begin{array}{l}\text { Gedung kantor yang } \\
\text { masih dalam masa sewa }\end{array}$ & $\begin{array}{c}0,044 \\
1\end{array}$ & 2 & 0,0882 & 2 & 0,0882 & 2,67 & 0,1176 & 3 & 0,1323 \\
\hline $\begin{array}{l}\text { Butuh penelitian dan } \\
\text { pengembangan kembali } \\
\text { tehadap produk }\end{array}$ & 0,077 & 2 & 0,154 & 2 & 0,154 & 3 & 0,231 & 2,67 & 0,2053 \\
\hline $\begin{array}{l}\text { Belum menggunakan } \\
\text { system informasi } \\
\text { Manajemen }\end{array}$ & $\begin{array}{c}0,065 \\
6\end{array}$ & $\begin{array}{c}3,3 \\
3\end{array}$ & $\begin{array}{c}0,2186 \\
7\end{array}$ & 3,33 & $\begin{array}{c}0,21866 \\
7\end{array}$ & 3 & 0,1968 & 3 & 0,1968 \\
\hline $\begin{array}{l}\text { Kurangnya pelatihan dan } \\
\text { pengembangan untuk } \\
\text { SDM }\end{array}$ & $\begin{array}{c}0,065 \\
6\end{array}$ & $\begin{array}{c}3,3 \\
3\end{array}$ & $\begin{array}{l}0,2186 \\
7\end{array}$ & 3,33 & $\begin{array}{c}0,21866 \\
7\end{array}$ & 3,33 & $\begin{array}{c}0,21866 \\
7\end{array}$ & 2,67 & $\begin{array}{c}0,1749 \\
3\end{array}$ \\
\hline \multicolumn{10}{|l|}{ Peluang } \\
\hline $\begin{array}{l}\text { Sedikitnya Pesaing } \\
\text { dalam Industri Ini }\end{array}$ & 0,101 & $\begin{array}{c}3,3 \\
3\end{array}$ & 0,3367 & 3,67 & 0,3703 & 3 & 0,303 & 3 & 0,303 \\
\hline $\begin{array}{l}\text { Kebutuhan masyarakat } \\
\text { akan parfume dalam } \\
\text { beraktifitas }\end{array}$ & $\begin{array}{c}0,093 \\
4\end{array}$ & 4 & 0,3736 & 4 & 0,3736 & 3,33 & 0,3113 & 3 & 0,2802 \\
\hline $\begin{array}{l}\text { Trend masyarakat dalam } \\
\text { berbelanja online }\end{array}$ & 0,091 & 4 & 0,364 & 4 & 0,364 & 3,33 & 0,3033 & 3,67 & 0,3337 \\
\hline $\begin{array}{l}\text { Meningkatnya UMR } \\
\text { masyarakat }\end{array}$ & $\begin{array}{c}0,094 \\
8\end{array}$ & 3 & 0,2844 & 3 & 0,2844 & 3 & 0,2844 & 3 & 0,2844 \\
\hline $\begin{array}{l}\text { Besarnya pangsa pasar } \\
\text { yang dapat diraih }\end{array}$ & $\begin{array}{c}0,098 \\
5 \\
\end{array}$ & $\begin{array}{c}3,6 \\
7 \\
\end{array}$ & 0,3612 & 3,67 & 0,3612 & 3 & 0,2955 & 3,67 & 0,3612 \\
\hline \multicolumn{10}{|l|}{ Ancaman } \\
\hline $\begin{array}{l}\text { Produk refill atau merek } \\
\text { lain }\end{array}$ & $\begin{array}{c}0,106 \\
1\end{array}$ & $\begin{array}{c}3,6 \\
7\end{array}$ & $\begin{array}{c}0,3890 \\
3\end{array}$ & 3,33 & $\begin{array}{c}0,35366 \\
7\end{array}$ & $\begin{array}{c}3,33 \\
3\end{array}$ & $\begin{array}{c}0,35366 \\
7\end{array}$ & 3 & 0,3183 \\
\hline Parfum Ori brandend & 0,081 & $\begin{array}{c}3,6 \\
7\end{array}$ & 0,297 & 3 & 0,243 & 3 & 0,243 & 2,67 & 0,216 \\
\hline Isu parfum Beralkohol & $\begin{array}{c}0,092 \\
3\end{array}$ & 3 & 0,2769 & 3 & 0,2769 & 3 & 0,2769 & 2,67 & $\begin{array}{c}0,2461 \\
3\end{array}$ \\
\hline $\begin{array}{l}\text { Kuantitas order terbatas } \\
\text { dari pemasok }\end{array}$ & 0,071 & $\begin{array}{c}2,6 \\
7\end{array}$ & $\begin{array}{c}0,1893 \\
3\end{array}$ & 2,67 & $\begin{array}{c}0,18933 \\
3\end{array}$ & 2,67 & $\begin{array}{c}0,18933 \\
3\end{array}$ & 3 & 0,213 \\
\hline Nilai tukar dolar & $\begin{array}{c}0,097 \\
3\end{array}$ & $\begin{array}{c}3,3 \\
3\end{array}$ & $\begin{array}{c}0,3243 \\
3 \\
\end{array}$ & 3,33 & $\begin{array}{c}0,32433 \\
3 \\
\end{array}$ & 3,33 & $\begin{array}{c}0,32433 \\
3\end{array}$ & 3,33 & $\begin{array}{c}0,3243 \\
3\end{array}$ \\
\hline $\begin{array}{l}\text { Pengiriman barang yang } \\
\text { dibatasi oleh pihak jasa } \\
\text { pengiriman barang }\end{array}$ & $\begin{array}{c}0,073 \\
6\end{array}$ & 3 & 0,2208 & 3 & 0,2208 & 2,67 & $\begin{array}{c}0,19626 \\
7\end{array}$ & 3 & 0,2208 \\
\hline & & & 6,6589 & & 6,4466 & & 6,39177 & & 6,1273 \\
\hline
\end{tabular}


Sumber : Data Primer yang diolah

Dari hasil perhitungan QSPM, diperoleh nilai keseluruhan TAS dari empat strategi alternative 1 sebesar 6,6589, strategi alternative 2 sebesar 6,4466 , strategi alternative 3 sebesar 6,39177 , dan alternative strategi 4 sebesar 6,1273.

Dari beberapa nilai TAS yang diperoleh, alternative strategi yang tertinggi yang menjadi pilihan utama. Maka alternative strategi 1 dengan bobot 6,6589 menjadi pilihan utama perusahaan. Diamana perusahaan mengahadapi banyaknya kekuatan untuk mendorong peluang yang ada, dan strategi ini berorientasi dengan meningktkan pertumbuhan perusahaan dan memanfaatkan sebaik mungkin situasi yang memungkinkan. Adapun yang dapat dilakukan perusahaan market development, market penetrasion, product development, forward integration.

\section{KESIMPULAN}

Berdasarkan analisis dan pembahasan yang telah dilakukan dapat disimpulkan Strategi bisnis yang yang telah dikembangkan oleh AZWA Parfume saat ini sudah sejalan dengan tuntutan persaingan yang dihadapi sekarang. Ini dibuktikan dengan meningkatnya target penjualan setiap tahunnya. Dari analisis matrik IFE ditemukan bahwa kekuatan utama yang dimiliki adalah Parfume AZWA yang original, unik, mewah dan halal dengan perolehan bobot 0,307852. Dengan analsis ini dapat dilihat bahwa melalui produk yang original, unik ,mewah dan halal adalah kunci keberhasilan strategis bisnis perusahaan. Dan skor total matrik EFE 3,389 menunjukan bahwa secara internal perusahaan memiliki banyak kekuatan dan mampu menangani kelemahan yang ada. Adapun Faktor Internal dan Eksternal terdiri dari kekuatan yang dimiliki AZWA perfume yaitu manajemen yang visioner dalam melihat peluang yang ada, budaya organisasi perusahaan sudah berjalan dengan baik, parfume AZWA original, unik, mewah dan halal, tersebarnya store resmi penjualan AZWA Parfume dibeberapa daerah, AZWA Parfume menjalin kerja sama dengan perusahaan jasa pengiriman seperti JNE,JNT dan Tiki dan media social merupakan salah satu kekuatan AZWA Parfume dalam meningkatkan penjualan. Kelemahan yang dimiliki AZWA perfume adalah realisasi penjualan yang tiap tahunnya belum mencapai target yang telah ditetapkan, promosi yang belum maksimal, botol kemasan yang belum memiliki Inovasi, jumlah outlat resmi AZWA Parfume yang belum tersebar secara merata, gedung kantor yang masih dalam masa sewa, butuh penelitian dan pengembangan kembali tehadap produk, belum menggunakan system informasi manajemen dan kurangnya pelatihan dan pengembangan untuk SDM

Adapun peluang yang miliki AZWA perfume yaitu sedikitnya Pesaing dalam Industri Ini, kebutuhan masyarakat akan parfume dalam beraktifitas, trend masyarakat dalam berbelanja online, meningkatnya UMR masyarakat dan besarnya pangsa pasar yang dapat diraih. Sedangkan ancaman yang perlu mendapatkan perhatian khusus yaitu produk refill atau merek lain, parfum Ori brandend, isu parfum beralkohol, kuantitas order terbatas dari pemasok dan pengiriman barang yang dibatasi oleh pihak jasa pengiriman barang.

Analisis QSPM, dari hasil Perhitungan QSPM, diperoleh nilai 
ISSN 1412-2936

EISSN 2549-7308

keseluruhan atau TAS (Total attractiveness score) dari empat alternative strategi. Ditemukan strategi yang tertinggi yang menjadi pilihan adalah strategi 4 yaitu Devensif . dengan banayaknya ancaman dari lingkungan luar, perusahaan harus bertahan dengan melakukan efisiensi dan mengoptimalkan sumber daya yang ada.

\section{DAFTAR PUSTAKA}

Bezborah \& Bhagawati. (2013). A Study on The Marketing Strategis Adopted South Indian Bank, Axis Bank and Standard Cartered Bank In Guwahati City. Asian journal of Research in Marketing, Vol.2,No.5,pp.27-37.

David, F. R. (2010). Strategic Management. Manajemen Strategis. Edisi Kedua belas, Buku Satu. Jakarta: Salemba Empat

Dirisu, Joy.l, dkk. (2013). Product Differentiation: $\quad A$ Tool Competitive Advantage and optimal Organizational Performance.European Scientific Journal Vol.9,No.34.

Hitt, Michael A., Ireland, R. Duane and Hoskisson, Robert E. (2001). Strategic Manajement: Competitiveness and Globalization, Edisi Bahasa Indonesia, Jakarta: Salemba Empat

Kotler, P, dan Armstrong G. (2008).

Prinsip-prinsip pemasaran. Jilid 1. Edisi

Kedua

belas. Jakarta: Erlangga,

Nisipeanu, Elena. 2013. "Determinants of the National Competitive Advantage (NCA). "Interational Journal of Academic Research in Business and Social

Sciences.

Porter, Michael E. (1996). What Is Strategy?. Harvard Business Review, 74,61-78. Harvard Busuness School Publishing Corporation.

Rangkuti, Freddy. (2008). Analisis SWOT Teknik Membedah Kasus Bisnis. Jakarta: PT.Gramedia Pustaka Utama Rahmady, R, dan Andi S. (2007). Konsentrasi Pemasaran. Surabaya: Badan Penerbit Mahardhika 